\title{
HARWELL RADIOCARBON MEASUREMENTS I
}

\author{
R L OTLET and B S SLADE
}

Nuclear Physics Division, Atomic Energy Research Establishment, Harwell, Berkshire, England

The Low-level Measurements Laboratory at AERE, Harwell was set up some years ago principally to measure natural levels of tritium in water for hydrologic applications. The measurement of ${ }^{14} \mathrm{C}$ in groundwater carbonates was a logical development from this work. In the period 1971-73 the measurement system has been extended to include archaeologic samples and this is the first list of dates for samples submitted during that period.

Liquid scintillation techniques are used for radiocarbon dating. Two Packard Model 3375 liquid scintillation spectrometers are used for counting. Benzene production essentially follows the method of Polach and Stipp (1967). A proprietary catalyst (Mobile Durabead I) is used for the acetylene trimerization stage but faster reaction time can be achieved if the already activated material is further activated with Vanadium. In the acetylene preparation, good yields $(96 \%)$, when handling up to $15 \mathrm{~L}$ of $\mathrm{CO}_{2}$, have been obtained working at ca $50 \% \mathrm{Li}$ excess.

In counting early samples, benzene produced was added to a Toluene based scintillator containing $0.4 \mathrm{~g} / 1 \mathrm{PPO}$ and $0.05 \mathrm{~g} / \mathrm{l}$ dimethyl POPOP, as suggested by Tamers (1965). An approximately constant mixture of $3 \mathrm{ml}$ benzene sample with $11 \mathrm{ml}$ Toluene was used. Since HAR-228, larger volume benzene samples (up to $8 \mathrm{ml}$ ) have been routinely produced and the Toluene scintillator dropped in favor of a proprietary benzene based liquid scintillator (NE 231A). This latter mixture allows a wide range of sample to scintillant proportions (eg, 1:13 up to $8: 6$ in $14 \mathrm{ml}$ total solution) with only slight changes in counting characteristics which can be fully allowed for using automatic external standardization (Packard Model 3375) reading. A further advantage is that in the event of a vial leaking during the counting period, a pro-rata correction, based on the observed weight loss, can be correctly applied. Leaking vials caused considerable difficulty in the initial setting up and testing period. Standard Packard vials leak with Toluene/Benzene to some degree, although with cooled counting units, leakage can easily be masked by an apparent gain in weight probably due to moisture absorption in the plastic lids. A good seal is now achieved with an Indium foil washer $(0.008 \mathrm{~cm})$ held firmly to the specially ground vial top by a rubber washer $(0.165 \mathrm{~cm})$ used in place of the usual cork/aluminium pressure pad. A Teflon washer $(0.026 \mathrm{~cm})$ in between prevents damage to the Indium when tightening the screw cap. With this seal it is possible to keep samples, eg, oxalic acid standards, for more than 12 months without loss. The 2 liquid scintillation spectrometers have similar characteristics for background $(-8.5 \mathrm{cpm})$ and efficiency $(-70 \%)$ at optimum S/VB settings (channels 100-600). Cycling 
and computational procedures similar to those described by Polach (1967) are employed.

All ages are calculated using the Libby half-life of 5570 years and 0.95 NBS oxalic modern standard with AD 1950 as reference year. Background samples from marble, coke, or fuel oil are routinely prepared to check background stability of the whole process with occasional calibration checks using freshly made NBS oxalic acid standards. In the latter case only dry combustion is used, which shows less scatter on results than wet techniques. Negligible fractionation occurs, thus avoiding $\delta^{13} \mathrm{C}$ corrections. ${ }^{13} \mathrm{C} /{ }^{12} \mathrm{C}$ ratios are measured by a subsidiary laboratory to ca $\pm 1 \%$. The published dates are all corrected for $\delta^{13} \mathrm{C}$ in the usual way (Broecker and Olson, 1961).

Standard deviations based on all accountable errors in the measurement process, eg, the allowance for background and calibration uncertainties is based on the observed long term reproducibility; and not merely on the counting statistics of the measured sample. Conventional pretreatment processes have been used throughout. Bone determinations are always based on collagen ages.

\section{ACKNOWLEDGMENTS}

We should like to acknowledge the support of our Group Leader, D B Smith and the work of our colleagues, D G Humphreys, G A Bradburn, and D B Punter. Our special thanks to the contributors of the samples for their comments and permission to publish their results in this list.

\section{ARCHAEOLOGIC SAMPLES}

\section{A. England \& Wales}

HAR-78. W I N

$$
6370 \pm 150
$$

$4420 \mathrm{BC}$

$\delta^{13} \mathrm{C}=-28.7 \%$

Wood from submerged forest stock, Newport Pembrokeshire $\left(52^{\circ} 1^{\prime}\right.$ $\left.35^{\prime \prime} \mathrm{N}, 4^{\circ} 50^{\prime} 30^{\prime \prime} \mathrm{W}\right)$. In situ in peat layer at mid-tide level, $-0.6 \mathrm{~m}$. Coll and subm by $\mathrm{C}$ Kidson. Comment (CK): date agrees with others from similar material from this level at other points in Cardigan Bay.

\section{St Aldates series, Oxford}

The samples are assoc with a low bank of blue clay at site of $79 / 80$ St Aldates (51 $44^{\prime} 46^{\prime \prime} \mathrm{N}, 1^{\circ} 15^{\prime} 20^{\prime \prime} \mathrm{W}$ ) which may be alluvial but could be man-made (Hassall, 1972). Coll and subm by $T$ G Hassall, 1971-72.

\section{HAR-79/85. Wattle 434}

$$
1120 \pm 110
$$

Vertical stake of hazel wood, $25 \mathrm{~mm}$ diam twig with bark, supporting a wattle fence set on the clay bank. The surface of the bank was unweathered; the clay had either been dumped, or radically reshaped 
shortly before erection of fence. Both were apparently rapidly sealed by layers of alluvium. Comment (TGH): result agrees well with ceramic and stratigraphic evidence. Pottery from clay surface was dated by thermoluminescence to $\mathrm{AD} 745 \pm 62$ (OX TL-141C).

\section{HAR-125. Wattle 472}

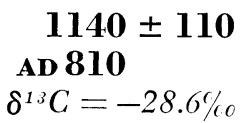

Hazel wood vertical stake that supported a low wattle fence but was set in alluvium on side of a clay bank. Comment (TGH): stratigraphically, date should be later than HAR-79/85 but result is generally satisfactory. The thermoluminescence date was also earlier than that relative to HAR-79/85, $i e$, AD $700 \pm 74$ (OX TL-141D).

\section{HAR-209. Lin Coll 46}

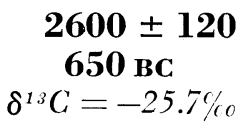

Seeds and soil from gritty silt overlying flood-plain gravel and sealed by thick blue clay assumed part of bank at 79/80 St Aldates on opposite side of road. Comment (TGH): if date is accurate for deposition of clay bank, the clay must be alluvial because a man-made structure of that date is almost inconceivable. If clay was man-made an earlier date than HAR-79/85 is expected, $i e$, late 8th century AD.

\section{HAR-190. Grave 2}

$$
\begin{array}{r}
1110 \pm 100 \\
\operatorname{AD} 840
\end{array}
$$$$
\delta^{13} \mathrm{C}=-28.4 \%
$$

Charcoal (probably oak) from a charcoal burial, $i e$, an extended inhumation on a bed of cold charcoal outside the $\mathrm{W}$ end of Christ Church Cathedral, Oxford (51 $\left.44^{\prime} 46^{\prime \prime} \mathrm{N}, 1^{\circ} 15^{\prime} 10^{\prime \prime} \mathrm{W}\right)$, presumed site of St Frideswide's minster, founded in the 8th century. Coll and subm by T G Hassall (1973). Comment (TGH): date confirms existence of religious activity on site in the 9th century and supports theory of a religious foundation in the 8th century. Pre-dates earliest certain documentary reference to St Frideswide's minster by $150 \mathrm{yr}$, and shows this form of burial was Saxon and not Danish as supposed.

\section{HAR-191. Wattle 80}

$730 \pm 100$

$$
\begin{aligned}
& \text { AD } 1220 \\
& \delta^{13} C=-28.4 \%
\end{aligned}
$$

Wood, $30 \mathrm{~mm}$ diam with bark, from a wattle fence in a silted-up ditch dug into alluvium on which the priory of Blackfriars, Oxford $\left(51^{\circ} 45^{\prime} 18^{\prime \prime} \mathrm{N}, 1^{\circ} 15^{\prime} 34^{\prime \prime} \mathrm{W}\right)$ was built. The ditch was sealed by floor levels of the priory. Coll and subm by T G Hassall (1973). Comment (TGH): result agrees well with documentary evidence of friars' arrival in Oxford in 1221. They began building priory ca 1236 and finished in 1245. Alluvium possibly accumulated as a result of late Saxon bridge building; the ditch was used for agriculture or land drainage shortly before the friars occupied the site. 


\section{Castle Hill series, Huddersfield}

Site of Iron age fortifications at Almondbury, $5.5 \mathrm{~km} \mathrm{~S}$ of Huddersfield $\left(53^{\circ} 37^{\prime} \mathrm{N}, 1^{\circ} 45^{\prime} \mathrm{W}\right)$. Coll and subm by W J Varley, 1971-72, unless noted otherwise (Varley, 1973).

\section{HAR-83. Site 35-2}

$$
\begin{gathered}
2410 \pm 110 \\
460 \mathrm{BC} \\
\delta^{13} C=-24.6 \%
\end{gathered}
$$

Charcoal ash from occupation floor behind inner rampart of Iron age defenses and sealed by burnt debris of destruction. Coll Oct 1972 by A Havercroft.

\section{HAR-84. 35-B}

$$
\begin{gathered}
2470 \pm 130 \\
520 \text { BC } \\
\delta^{13} C=-27.0 \%
\end{gathered}
$$

Charcoal (Quercus sessiliflorus) from a charred log at base of inner rampart of Bivallate Fort, the penultimate stage of Iron age defenses. Part of sample was also sent to Isotopes, Inc for dating: I-5931: $2540 \pm 95$.

HAR-135. Site 31-11

$$
\begin{gathered}
2400 \pm 110 \\
450 \text { BC } \\
\delta^{13} C=-24.9 \%
\end{gathered}
$$

Charcoal ash from occupation floor immediately behind inner rampart of Iron age defenses and sealed by burnt debris of destruction. Coll July 1970 by A Challis. Comment (WJV): result confirms that for HAR-83.

HAR-143. Site 32, Stake

$$
\begin{array}{r}
\mathbf{8 0 0} \pm 100 \\
\text { AD } 1150 \\
\delta^{13} C=-24.4 \%
\end{array}
$$

Wood stake found point upwards at corner of boat-shaped pit containing coins (1160-1250) and medieval pottery (12th-13th century AD). Coll July 1970 by A Havercroft. Comment (WJV): confirms historic view that upper portion of visible earthworks was erected in the 12th century AD.

\section{HAR-182. Site 40, Lowest level}

$$
\begin{gathered}
4060 \pm 130 \\
2110 \text { BC } \\
\delta^{13} C=-24.5 \%
\end{gathered}
$$

Charcoal from occupation floor underlying earliest defenses. Coll June 1972 by B Slade.

HAR-183. Site 40

$$
\begin{gathered}
2480 \pm 110 \\
530 \text { BC } \\
\delta^{13} C=-23.8 \%
\end{gathered}
$$

Charcoal (Quercus sessiliflorus) from a timber insert in base of inner rampart (subsequently charred) at SW end of Iron age defenses.

\section{Rams Hill series}

Bronze age earthwork enclosure at Rams Hill, Berkshire $\left(51^{\circ} 34^{\prime}\right.$ $\left.30^{\prime \prime} \mathrm{N}, 1^{\circ} 32^{\prime} 56^{\prime \prime} \mathrm{W}\right)$. Five samples from $\mathrm{S}$ entrance of Bronze age 
ditched and palisaded enclosure lying within the defensive circuit of an early Iron age hill fort. Sequence probably begins with a ditched enclosure dated by an early Bronze age collared urn found in excavations of 1938-39 and continues through successive palisaded enclosures. Samples refer to later phases. HAR-232 is from a palisade that was either a freestanding enclosure or revetment to a rubble bank (Piggott and Piggott, 1940; Bradley and Ellison, 1973). Samples coll and subm Dec 1972 by R Bradley and A Ellison.

\section{HAR-228. Sample 113}

$$
\begin{gathered}
3020 \pm 90 \\
1070 \text { BC } \\
\delta^{13} C=-26.5 \%
\end{gathered}
$$

Charcoal from a post hole within palisade flanking $W$ terminal of $\mathrm{S}$ entrance. Comment (RB\&AE): dates outer line of double palisaded enclosure; inner line is dated by HAR-229.

HAR-229. Sample 114

$2960 \pm 80$

$1010 \mathrm{BC}$

$\delta^{13} \mathrm{C}=-25.5 \%$

Ash, etc from filling of inner line of double palisaded enclosure cutting W terminal of $\mathrm{S}$ entrance. Comment (RB\&AE): see HAR-228, above.

\section{HAR-230. Sample 163}

$$
\begin{array}{r}
2690 \pm 70 \\
740 \text { BC } \\
\delta^{13} C=-24.3 \%
\end{array}
$$

Charcoal from a patch within sarsen packing, cutting primary levels of $\mathrm{S}$ entrance (E terminal). Comment (RB\&AE): dates possible palisaded enclosure secondary to ditch of entrance. Compared with HAR-231, date seems too young.

\section{HAR-231. Post Holes, 168}

$$
\begin{gathered}
\mathbf{3 0 0 0} \pm \mathbf{9 0} \\
1050 \mathrm{BC} \\
\delta^{13} \mathrm{C}=-23.9 \%
\end{gathered}
$$

Charcoal from 2 patches within sarsen packing, cutting primary levels of $\mathrm{S}$ entrance (E terminal). Comment (RB\&AE): see HAR-230, above.

\section{HAR-232. Sample 197}

$$
\begin{gathered}
3010 \pm 70 \\
1060 \text { BC } \\
\delta^{13} C=-26.1 \%
\end{gathered}
$$

Charcoal from chalk packing of palisade trench within enclosure at $S$ entrance. Comment (RB\&AE): dates palisade trench, possibly reveting a rubble rampart within $S$ entrance, or part of a free standing enclosure.

\section{Longbridge Deverill series, Wiltshire}

Iron age settlement (Valera, 1961) at Longbridge Deverill Cow Down, Wiltshire $\left(51^{\circ} 10^{\prime} \mathrm{N}, 2^{\circ} 10^{\prime} \mathrm{W}\right)$. Samples coll Sept 1960 and subm Nov 1972 by Mrs S C Hawkes. Other dates from site were previ- 
ously reported: NPL-104 (R, 1966, v 8, p 340) and NPL-105-106 (R, 1968, v 10, p 115-116).

NB: House 4 given here is called House 3 and, similarly, House 3 here is called House 4 in the 1st ref (Valera, 1961).

HAR-253. Pit 37 (Bottom)

Carbonized grain, mainly barley, from Layer 4, base of grain storage pit. Stratified below charcoal sample in Layer 3, previously dated, NPL-109: $490 \pm 90$ вс. Comment $(\mathrm{SCH})$ : agrees very closely with NPL results for charcoal from same pit, but both dates are higher (earlier) than expected on archaeologic grounds.

HAR-254. PH 198, House 4

$$
\begin{gathered}
2420 \pm 60 \\
470 \mathrm{BC} \\
\delta^{13} \mathrm{C}=-25.7 \%
\end{gathered}
$$

Charcoal (Quercus robur) sample from charred stump of post in main ring post-circle. From smallest of 4 Iron age round houses on site.

\section{HAR-255. PH 104, House 3}

Charcoal (Quercus robur) sample from base of charred post in main ring structural post circle, from latest of 4 large Iron age round houses on site. Comment (SCH): date is just about as expected.

\section{HAR-256. PH 217, House 4}

$$
\begin{gathered}
2440 \pm 90 \\
490 \text { BC } \\
\delta^{13} C=-24.7 \%
\end{gathered}
$$

Charcoal (Quercus robur) from base of charred post in porch of House 4. Comment (SCH): agrees well with other sample from same house (HAR-254) and date is as expected.

\section{Winchester Research Unit series}

Samples from excavations at Winchester, England by above unit (Biddle, 1970; 1972; 1974). Coll June 1969 to Sept 1971 and subm Feb 1973 by M Biddle.

\section{HAR-288. Brook Street, F 778}

$$
\begin{gathered}
\mathbf{1 2 4 0} \pm \mathbf{6 0} \\
\text { AD 710 } \\
\delta^{13} C=-26.0 \%
\end{gathered}
$$

Part of timber-lined well, Trench III, House XI, Layer 2670 (BS 71-1199); pre-dating the main sequence of house structures $\left(51^{\circ} 33^{\prime} 37^{\prime \prime} \mathrm{N}\right.$, $\left.1^{\circ} 18^{\prime} 39^{\prime \prime} \mathrm{W}\right)$. Comment (MB): surviving timber shows that ca 48 rings should be added to this date, plus an unknown number for timber lost in squaring up. A date of at least AD $760 \pm 60$ is therefore indicated. Correction (Switsur, 1973) of the raw radiocarbon date suggests, however, AD $742 \pm 60$, as calendar age of sample. Allowing for surviving 
outer rings, $\mathrm{Ca} A \mathrm{AD} 790 \pm 60$ is suggested, falling in the period of preurban development on site.

HAR-293. Wolvesey Palace, F 2370

$$
880 \pm 60
$$
AD 1070

$\delta^{13} C=-26.6 \%$

Wood from foundation timbers of West Hall of Wolvesey Palace $\left(51^{\circ} 3^{\prime} 24^{\prime \prime} \mathrm{N}, 1^{\circ} 18^{\prime} 39^{\prime \prime} \mathrm{W}\right.$ ), Room 41-40, (WP 71-70); 27 rings from center-total 34 rings. Comment (MB): surviving timber shows that at least 7 rings should be added to date. Calibration (Switsur, 1973) of raw radiocarbon date suggests, however, AD $1088 \pm 60$ as the calendar age of the sample. Allowing for surviving outer rings, Ca AD $1095 \pm 60$ is suggested. Since further rings are certainly missing, and the date suggested for the $\mathrm{W}$ Hall on archaeologic and architectural grounds is ca 1110 , the ${ }^{14} \mathrm{C}$ date and other indications agree completely.

\section{HAR-294. Southgate Street, Burial 1, 1971}

$$
\begin{gathered}
1240 \pm 70 \\
\text { AD 710 } \\
\delta^{13} C=-22.0 \%
\end{gathered}
$$

Human bone rib cage, vertebrae and pelvis from burial on uppermost silt of ditch barring access through Roman $\mathrm{S}$ gate of Winchester $\left(51^{\circ} 3^{\prime} 26^{\prime \prime} \mathrm{N}, 1^{\circ} 19^{\prime} 10^{\prime \prime} \mathrm{W}\right)$. Comment (MB): calibration (Switsur, 1973) of the raw radiocarbon date suggests AD $742 \pm 70$ as calendar age of sample. It was believed burial might date to mid-5th to later 6th century AD, but any date between Ca AD 450 and ca 880 was possible. Reconsideration of the relative sequence of the site in light of the radiocarbon date tends to confirm its probable accuracy.

\section{HAR-295. Castle Yard 1969, Layer 1528}

$$
\begin{gathered}
1070 \pm 60 \\
\mathbf{A D} 880 \\
\delta^{13} C=-24.0 \%
\end{gathered}
$$

Animal bone from occupation rubbish on surface of earliest of 8 Anglo Saxon (pre-1067) streets $\left(51^{\circ} 3^{\prime} 37^{\prime \prime} \mathrm{N}, 1^{\circ} 19^{\prime} 10^{\prime \prime} \mathrm{W}\right)$. Comment (MB): calibration (Switsur, 1973) of raw radiocarbon date suggests AD $902 \pm 60$ as calendar age of sample. According to Biddle (1970, p 287) the street is laid out "not later than the mid-10th century and probably before ca 904". Subsequently, historic date is refined to ca 880-886, thus agreeing with ${ }^{14} \mathrm{C}$ date.

\section{Castercliff series}

Site of a hill fort at Castercliff, Nelson, Lancashire $\left(53^{\circ} 50^{\prime} 26^{\prime \prime} \mathrm{N}\right.$, $\left.2^{\circ} 10^{\prime} 38^{\prime \prime} \mathrm{W}\right)$. Col and subm by D G Coombs, Manchester Univ.

\section{HAR-287. CC70 I(1)}

$2460 \pm 60$ $510 \mathrm{BC}$

$$
\delta^{13} C=-25.3 \%
$$

Charcoal from charred end of a post from back revetment of a narrow timber box rampart. Comment (DGC): the end of the post was burnt before insertion to prevent rapid decay. Thus, dates construction 
of unfinished outer rampart of fort, and agrees well with other recent dates for similar ramparts.

HAR-286. CC71 Al(a)

$$
\begin{gathered}
2460 \pm 70 \\
\mathbf{5 1 0} \mathbf{B C} \\
\delta^{13} C=-25.4 \%
\end{gathered}
$$

Charcoal from a burnt beam on the old ground surface under a nitrified inner rampart to which timber belonged. Comment (DGC): date agrees well with other recent dates for similar ramparts.

\section{B. Scotland}

\section{HAR-157. Shieldaig, Sample 1}

$$
\begin{gathered}
4030 \pm 120 \\
2080 \mathrm{BC} \\
\delta^{1 s} C=-26.4 \% \text { o }
\end{gathered}
$$

Unburnt wood from sandy soil underlying peat at Shieldaig, Wester Ross, Scotland $\left(57^{\circ} 30^{\prime} 45^{\prime \prime} \mathrm{N}, 5^{\circ} 39^{\prime} 30^{\prime \prime} \mathrm{W}\right)$. Reportedly from deeper sand where battered back microlithic flints were found. Precise relation of wood to flints is unknown. Coll Aug 1970 by A Macaulay and subm Feb 1972 by M J Walker. Comment (MJW): wood may have been part of an artifact, perhaps a trap, as it was perforated and roughly fusiform in shape. It was part of a surface colln of lithic and other material revealed during gravel-working and road-building operations, and dated to determine if it was of prehistoric age. Subsequent archaeologic excavations (1973) were undertaken by MJW in nearby undisturbed ground. See comment for HAR-163, below.

\section{HAR-163. Shieldaig, Sample 2}

$$
\begin{gathered}
\mathbf{3 7 2 0} \pm \mathbf{5 2 5} \\
\mathbf{1 7 7 0} \text { BC } \\
\delta^{13} C=-26.0 \%
\end{gathered}
$$

Charcoal from peat overlying sandy soil in which battered back type flints were found, and ca $40 \mathrm{~cm}$ below surface at Shieldaig, Wester Ross, Scotland $\left(57^{\circ} 30^{\prime} 4^{\prime \prime} \mathrm{N}, 5^{\circ} 40^{\prime} 5^{\prime \prime} \mathrm{E}\right)$. Coll and subm April 1972 by M J Walker. Comment (MJW): despite large error term, because of small sample size, date is acceptable for late Atlantic/early sub-Boreal pine forest. Sample was removed from exposed face of gravel pit before adjacent excavation was made in 1973, which revealed extensive remains of pine forest at approx same depth below surface, but overlying an ancient sand dune. Upper $10 \mathrm{~cm}$ of dune contained Mesolithic flint, quartz, and bloodstone chipped lithic assemblage. Dune probably accumulated during 5th millennium BC, and Mesolithic assemblage followed but preceded subsequent afforestation. Hopefully, more pine remains will be dated and palynologic studies will further assist chronologic assignment of occupation.

\section{HAR-158. Glenbane Hole, Sample 1}

$$
\begin{gathered}
2560 \pm 525 \\
610 \text { BC } \\
\delta^{13} C=-26.0 \%
\end{gathered}
$$

Charcoal from side of eroded deposit in entrance chamber at Glenbane Hole, Inchnadamph, Sutherland (58 $\left.5^{\prime} 10^{\prime \prime} \mathrm{N}, 4^{\circ} 58^{\prime} \mathrm{W}\right)$, from 
various layers in uniform deposit some $2 \mathrm{~m}$ deep against $\mathrm{E}$ wall of entrance chamber (Walker, 1973). Comments: insufficient sample for more accurate results. (MJW): eroded clay in entrance chamber of cave showed flecks of charcoal in exposed sec. Samples were dated in the interest of prehistoric archaeology since other caves with sediments containing prehistoric material were nearby. No archaeologic material was found in the cave. Date, despite high error term, suggests that the sediments may be old, if not perhaps quite as old as other cave deposits in $\mathrm{W}$ Sutherland.

$$
\text { C. Spain }
$$

\section{HAR-146. El Prado, Sample 1}

$$
\begin{gathered}
4080 \pm 130 \\
2130 \mathrm{BC} \\
\delta^{13} C=-21.4 \%
\end{gathered}
$$

Unburnt bone from surface of fields; probably from a Copper age settlement disturbed by ploughing at Jumilla, Murcia $\left(38^{\circ} 27^{\prime} 32^{\prime \prime} \mathrm{N}\right.$, $\left.1^{\circ} 19^{\prime} 24^{\prime \prime} \mathrm{W}\right)$. Coll Aug 1969 by J Molina and M J Walker. Subm Feb 1972 by MJW. Comment (MJW): although sample was from unstratified soil, radiocarbon date agrees well with other ceramic and lithic material coll by J Molina at same station indicating a Copper age settlement at El Prado.

\section{HAR-155. Terrera Venturas, Samples 1 and 2}

$$
\begin{gathered}
\mathbf{5 3 7 0} \pm \mathbf{3 5 0} \\
\mathbf{3 4 2 0} \mathbf{\text { BC }} \\
\delta^{13} \mathrm{C}=-26.0 \% \text { }
\end{gathered}
$$

Two charcoal samples put together from the side of an old archaeologic sec, $1.00 \mathrm{~m}$ below surface of the same Copper age settlement at

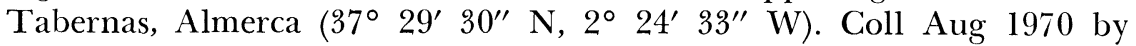
F G Jiménez and M J Walker. Subm Feb 1972 by MJW. Comments: larger than usual error term for this age is due to insufficient sample, even when added together. (MJW): radiocarbon date suggests a very early Copper age occupation. Recent excavations (Gusi, pers commun) uncovered 3 stratigraphic levels; the uppermost, which contains Beaker pottery, might correspond to later radiocarbon date. The site is extensive, and an occupation lasting perhaps 1000 yr might not be totally unacceptable, despite surprisingly early date.

\section{HAR-298. Terrera Venturas, Sample 3}

$$
\begin{gathered}
4030 \pm 80 \\
\mathbf{2 0 8 0} \text { BC } \\
\delta^{13} C=-21.3 \%
\end{gathered}
$$

Charcoal from side of old archaeologic sec at ca $0.50 \mathrm{~m}$ below surface. Copper age settlement as described for HAR-155. Coll Aug 1970 by F G Jiménez and subm Feb 1972 by M J Walker. Comment (MJW): date perhaps corresponds to phase of Copper age occupation characterized by Beaker pottery, subsequently defined by recent excavations (Gusi, pers commun). 
HAR-160. Cueva de los Tiestos (Cueva de los Murciélagos)

\author{
$3790 \pm 115$ \\ 1840 BC \\ $\delta^{13} \mathrm{C}=-22.3 \%$
}

Burnt barley from a sealed Copper age interment in a cave at Jumilla, Murcia (38 29' 48" N, $\left.1^{\circ} 22^{\prime} 14^{\prime \prime} \mathrm{W}\right)$. Coll Aug 1969 by J Molina and subm Feb 1972 by M J Walker. Comment (MJW): material from excavations indicates that assemblage is Copper age burial typical of SE Spain. Date agrees well with archaeologic assessment. The burial cave is perhaps roughly contemporary with the El Prado site, dated by HAR-146, above.

\title{
HAR-177-III. Cerro de Juan Climaco, Sample 1
}

$$
\begin{gathered}
2740 \pm 110 \\
790 \text { BC } \\
\delta^{13} C=-17.1 \%
\end{gathered}
$$

Unburnt bones from ground surface and sides of gullies that eroded prehistoric deposits on above site at Rambla de Lebor, Totana, Murcia $\left(37^{\circ} 45^{\prime} 36^{\prime \prime} \mathrm{N}, 1^{\circ} 33^{\prime} 56^{\prime \prime} \mathrm{W}\right)$. Coll Dec 1968 and subm Feb 1972 by M J Walker. Comment (MJW): material coll here is of Copper age. Radiocarbon determination on surface material suggests a later attribution. However, the bones could well be from later animals, as there is an extensive nearby Bronze age settlement (La Bastida). Another possibility is that the Juan Climaco site is really contemporary with the latter.

\section{HAR-178-III. El Castillico, Sample 1}

$$
\begin{aligned}
& 1500 \pm 100 \\
& \text { AD 450 } \\
& \delta^{13} C=-21.4 \%
\end{aligned}
$$

Unburnt animal bone from sealed deposits of an early Iron age dwelling at Corral de los Villaricos, El Sabinar, Moratalla, Murcia $\left(38^{\circ}\right.$ $10^{\prime} 52^{\prime \prime} \mathrm{N}, 2^{\circ} 11^{\prime} 18^{\prime \prime} \mathrm{W}$ ) (Walker, 1971, p 139). Coll Aug 1969 and subm Feb 1972 by M J Walker. Comment (MJW): date disagrees with archaeologic assignment of settlement. Sample is probably contaminated by later deposits since cultural context of site is at least $1000 \mathrm{yr}$ earlier than radiocarbon date.

\section{HAR-179-III. Abrigo Grande, Sample 2 \\ $7200 \pm 160$ $5250 \mathrm{BC}$$$
\delta^{13} C=-17.5 \%
$$

Animal bones from Layers 1 and 2, Barranco de Grajos, Cieza, Murcia $\left(38^{\circ} 15^{\prime} 55^{\prime \prime} \mathrm{N}, 1^{\circ} 22^{\prime} 54^{\prime \prime} \mathrm{W}\right)$. Coll Sept 1970 and subm Feb 1972 by M J Walker. Comment (MJW): layers in which bones occurred contained non-geometric flint industry and plain and impressed pottery, overlying layers with similar flints but lacking pottery in aeolian sands and thermoclastic scree, respectively (Layers 3 and 4). One sherd of cardial impressed pottery, found on the surface, was similar to those of other sites in France and Italy, as well as from a slightly later date at another site (Coveta de l'or) in SE Spain. Site demonstrates continuity of lithic traditions from aceramic to ceramic containing layers. A nearby rock shelter contains anthropomorphic rock paintings and animal depic- 
tions. This acceptable radiocarbon date for the onset of the Neolithic in SE Spain might also give context for some naturalistic rock art in the area (Walker, 1970).

HAR-180. Abrigo Grande, Samples 1 and 3

$5120 \pm 620$

Charcoal, Sample 1, and bone, Sample 3, from Barranco de los Grajos, Cieza, Murcia (38 $\left.18^{\prime} 55^{\prime \prime} \mathrm{N}, 1^{\circ} 22^{\prime} 54^{\prime \prime} \mathrm{W}\right)$. Charcoal from lowest layer, 4, close to bed-rock of cave shelter, in an aceramic layer with Epipalaeolithic implements, similar to overlying Layer 3. Bone from Layers 2 and 4. Coll Sept 1970 and subm Feb 1972 by M J Walker. Comment: large error due to insufficient sample. Comment (MJW): date is doubtful in view of acceptability of HAR-179-III for overlying layers. Bone may have been from later disturbance, since some came from an excavation with traces of disturbance.

HAR-193. Villena, Sample A

$$
\begin{array}{r}
>\mathbf{3 2 , 0 0 0} \\
\delta^{13} C=-27.3 \%
\end{array}
$$

Peat from a Quaternary deposit (Cuenca Paya, 1973), from -11 to $-14 \mathrm{~m}$, of Vinalopó valley, Alicante $\left(38^{\circ} 38^{\prime} \mathrm{N}, 0^{\circ} 52^{\prime} \mathrm{W}\right)$. Coll Aug 1971 by A Cuenca Paya and subm Feb 1972 by M J Walker. Comment: (MJW): peat layer is stratified below and above gley soils and clays with intercolated sandy lenses. Uppermost $8 \mathrm{~m}$ of column comprised postglacial aeolian sands. Radiocarbon date of last glacial age from the peat is therefore acceptable.

\section{Woodhall Spa series}

$$
\text { II. GEOLOGIC SAMPLES }
$$

\section{A. England \& Wales}

Fen peat samples from sites near Woodhall Spa, Lincolnshire (K Valentine, 1973). Coll and subm Aug 1971 by K Valentine, Reading Univ. Other samples from same horizons were dated by Radiocarbon Dating Lab, Stockholm, and are noted.

\section{HAR-147. Sample 499}

$$
\begin{gathered}
4080 \pm 130 \\
2130 \mathrm{BC} \\
\delta^{13} C=-27.0 \%
\end{gathered}
$$

From basal layer of peat overlain by blue-gray clay and overlying a Groundwater Gley soil in coarse sand and clay 206 to $211 \mathrm{~cm}$ below surface at Timberland Dales $\left(53^{\circ} 8^{\prime} \mathrm{N}, 0^{\circ} 14^{\prime} \mathrm{W}\right)$. Comment: compares with Stockholm result, IGS-C14/111: $3980 \pm 100$.

\section{HAR-148. Sample 502}

HAR-189. Sample 502

$$
\begin{gathered}
\mathbf{3 7 7 0} \pm \mathbf{1 3 0} \\
\mathbf{1 8 2 0} \mathbf{\mathrm { BC }} \\
\delta^{13} C=-26.2 \% \\
\mathbf{3 9 5 0} \pm \mathbf{1 2 0} \\
\mathbf{2 0 0 0} \mathbf{\mathrm { BC }} \\
\delta^{13} \mathrm{C}=-27.3 \%
\end{gathered}
$$

From basal layer of peat overlain by blue-gray clay and overlying a 
Gley Podzol paleosol in coarse sand and gravel 223 to $228 \mathrm{~cm}$ below surface at Tattershall Bridge $\left(53^{\circ} 5^{\prime} \mathrm{N}, 0^{\circ} 13^{\prime} \mathrm{W}\right)$. Comment: 2nd measurement, HAR-189, from same sample was made because Stockholm result, IGS-G14/112: $4130 \pm 100$, from material from the same horizon, Sample 510, seemed significantly older. The 2 nd result agrees better but over-all scatter may be indicative of a non-contemporary contaminant that could not be successfully removed in pretreatment processes.

\section{HAR-149. Sample 494}

$$
\begin{gathered}
3620 \pm 130 \\
1670 \mathrm{BC} \\
\delta^{13} C=-25.6 \%
\end{gathered}
$$

From basal peat overlain by blue-gray fen clay and overlying Humus Iron Podzol in coarse sand 123 to $128 \mathrm{~cm}$ below surface at Thorpe Tilney Dales $\left(53^{\circ} 7^{\prime} \mathrm{N}, 0^{\circ} 14^{\prime} \mathrm{W}\right)$. Comment $(\mathrm{KV})$ : date is more recent than others in series possibly because it is much nearer the surface and subject to contamination by modern roots.

\section{HAR-150. Sample 492}

$$
4160 \pm 130
$$

$$
\begin{gathered}
\mathbf{2 2 1 0} \mathbf{\text { BC}} \\
\delta^{13} \mathrm{C}=-27.3 \%
\end{gathered}
$$

From upper layer of peat overlain by blue-gray fen clay and overlying coarse sand containing Groundwater Gley paleosol, 235 to $239 \mathrm{~cm}$ below surface at Kirkstead Bridge $\left(53^{\circ} 8^{\prime} \mathrm{N}, 0^{\circ} 15^{\prime} \mathrm{W}\right)$. Comment: comparable with Stockholm result, IGS-C14/109: $3945 \pm 100$.

\section{HAR-151. Sample 504}

$4120 \pm 130$ 2170 BC

From basal peat overlain by blue-gray fen clay and overlying a Humus Iron Podzol paleosol in coarse sand 180 to $185 \mathrm{~cm}$ below surface at Timberland Dales $\left(53^{\circ} 8^{\prime} \mathrm{N}, 0^{\circ} 14^{\prime} \mathrm{W}\right)$. Comment $(\mathrm{KV})$ : sample was not measured by Stockholm but is only a few $m$ away from Sample 499 (HAR-147) qv.

\section{HAR-192. Sample 490}

$$
4210 \pm 120
$$

$$
\delta^{13} \mathrm{C}=-27.4 \%
$$

From basal layer of peat overlain by blue-gray clay overlying Groundwater Gley paleosol in coarse sand 255 to $260 \mathrm{~cm}$ below surface at Kirkstead Bridge $\left(53^{\circ} 8^{\prime} \mathrm{N}, 0^{\circ} 15^{\prime} \mathrm{W}\right)$. Comment $(\mathrm{KV})$ : upper layer of same peat from profile dated as HAR-150, $q v$.

\section{Sproughton series}

These samples comprise 2 groups: HAR-260, a branch enclosed in organic silt, and HAR-259, -261, and -262, which consist of twigs and leaves from cross-bedded sands in thick sediment of fluvial sands and gravels. The organic silts are dissected by a buried channel, infilled by the fluvial sands and gravels. All deposits are exposed in a gravel pit excavated into the base of the Gipping valley beneath the present flood 
plain at Sproughton, Ipswich $\left(52^{\circ} 3^{\prime} 26^{\prime \prime} \mathrm{N}, 1^{\circ} 7^{\prime} 18^{\prime \prime} \mathrm{E}\right)$. Coll and subm by J Rose, Birbeck College, Univ London.

General Comment (JR): ${ }^{14} \mathrm{C}$ date of organic silt suggests deposit accumulated during Weichselian Late Glacial Thermal Optimum (Late Older Dryas/Early Aller $\phi \mathrm{d}$ ), while ${ }^{14} \mathrm{C}$ dates from sands and gravels indicate fluvial aggradation during Weichselian Late Glacial Climatic Deterioration (Late Aller $\phi \mathrm{d} /$ Younger Dryas) and initial part of Flandrian. The unconformity between the 2 deposits indicates river dissection sometime after 11,940 BP and before deposition of base of sands and gravels that include organic material dated 11,640 BP (Rose, 1973). Samples coll and subm by J Rose.

\section{HAR-259. Sample 1}

$9880 \pm 120$

$7930 \mathrm{BC}$

$\delta^{13} C=-29.6 \%$

Willow twigs (Salix spp) from organic fragments enclosed in small scale, sand cross-set, near top of fluvial sands and gravels. Alt: $+1.0 \mathrm{~m}$.

\section{HAR-260. Sample 14}

$11,940 \pm 180$ 9990 BC

$\delta^{13} C=-26.4 \%$

Wood from a single branch enclosed in organic silt, separated by an unconformity from fluvial sands and gravels in a stratigraphically lower position. Alt: $+1.40 \mathrm{~m}$.

HAR-261. Sample 105

$$
\begin{gathered}
11,640 \pm 500 \\
9690 \text { BC } \\
\delta^{13} C=-28.2 \%
\end{gathered}
$$

Fresh wood and leaf fragments from organic detritus on surface of a large scale, cross-bedded sand structure in lower part of fluvial sands and gravels. Alt: $-4.08 \mathrm{~m}$.

\section{HAR-262. Sample 108}

$$
\begin{gathered}
11,370 \pm 210 \\
9420 \mathrm{BC} \\
\delta^{13} C=-28.8 \%
\end{gathered}
$$

Wood, leaf, and peat fragments from organic detritus resting on surface of a large, scale cross-bedded sand structure in lower part of fluvial sands and gravels. Alt: $-3.76 \mathrm{~m}$.

\section{B. Norway}

\section{Austre Okstinbreen series}

Organic material (peat) from a neoglacial maximum end moraine at Austre Okstindbedal, Okstindan Mts, Nordland, Norway $\left(66^{\circ} 2^{\prime} \mathrm{N}\right.$, $14^{\circ} 23^{\prime}$ E). Samples subm Nov 1972 by P Worsley (Alexander, 1970, p 25; Alexander and Worsley, 1973). 
HAR-257. Bed 2, Pit 1

\author{
$1600 \pm 90$ \\ AD 350 \\ $\delta^{1 s} \mathrm{C}=-26.8 \%$ o
}

Coll by $\mathrm{P}$ Worsley. Comment (PW): demonstrates that end moraine is post AD 0 and may be assoc with widespread glacial maximum in Scandinavia during 18 th century AD.

HAR-258. Bed 2, Pit 1

$6280 \pm 110$

4330 BC

$\delta^{13} C=-24.4 \%$

Coll by N Griffey. Comment (PW): dates from Holocene climatic optimum and suggests that moraine ridge post-dates this period.

\title{
REFERENCES
}

Alexander, M J, 1970, A study of some soils in the Austre Okstindbredal area, in: Worsley, P (ed), Preliminary Report 1968: Okstindan Research Project, Univ Reading, England, p 25-31.

Alexander, M and Worsley, P, 1973, On the stratigraphy of a neoglacial end moraine Austre Okstindbredal: North Norway, Boreas, v 2, in press.

Biddle, M, 1970, Excavations at Winchester 1969, 18th interim report: Antiquaries Jour, v 50, p 285-289; 322-323.

1972, Excavations at Winchester 1970, 9th interim report: Antiquaries Jour, v 52, p 126.

1974, Excavations at Winchester 1971, 10th and final interim report: Antiquaries Jour, v 54, in press.

Bradley, R and Ellison, A, 1973, Rams Hill: Current Archacol, v 4, no 36, p 8-10.

Broecker, W S and Olson, E A, 1961, Lamont radiocarbon measurements VIII: Radiocarbon, v 3, p 176-204.

Cuenca Paya, A, El cuarternario reciente en la cuenca del Vinalopo (Alicante): Estudios Geologicos, mss in preparation.

Hassall, T G, 1972, Excavations at Oxford 1971, 4th interim report: Oxoniensia, v $37, \mathrm{p} 145,147$.

in press.

Piggott, S and Piggott, C, 1940, Excavations at Rams Hill, Uffington, Berkshire, England: Antiquaries Jour, v 20, p 465-480.

Polach, H A and Stipp, J J, 1967, Improved synthesis techniques for methane and benzene radiocarbon dating: Jour Appl Radiation and Isotopes, v 18, p 359-364. 1969 . Optimisation of liquid scintillation radiocarbon age determinations and reporting of ages: Atomic Energy in Australia, v 12, no 3, p 21-28.

Rose, J, 1973, Sproughton: Handbook Quaternary Res Assoc, Clacton, UK, p 91-96.

Switsur, V R, 1973, The radiocarbon calendar recalibrated: Antiquity, v 47, p 131-137.

Tamers, M A, 1965, Routine carbon-14 dating using liquid scintillation technique: 6 th internatl conf on radiocarbon and tritium dating, Proc, Pullman, Washington, p 53-67.

Valentine, K W G, 1973, The identification, laterial variation and chronology of three buried paleocatenas in lowland, England: PhD Thesis, Univ Reading, UK, 212 pages.

Valera, R de, 1961, The Carlingford culture, the long barrow and Neolithic of Great Britain and Ireland: Prehistoric Soc Proc, v 27, no 10, p 234-252.

Varley, W J, 1973, A brief guide to the excavations of Castle Hill, Almondbury, 1939-72: Huddersfield, Tolson Memorial Mus.

Walker, M J, Excavaciones preliminares en al Abrigo Grande del Barranco de Grajos, termino de Cieza, Murcia, 1970, contribucion al estudio del periodo neotermal en la peninsola: Noticiario Arqueotogico Hispanico, mss in preparation.

1971, Excavaciones en El Castillico, Corral de los Villaricos, El Sabinar, termino de Moratalla, Murcia, 1969: Noticiario Arqueotogico Hispanico, v 13-14,

p 139-162. 1973 , A radiocarbon date from Glenbane Hole, Sutherland: Cave Research Group of Great Britain Newsletter, v 134, p 7. 